\title{
KAYSERi AŞIKLIK GELENEĞiNDE AŞIK MAZLUM BERRAKî
}

\author{
Âşık Mazlum Berraki in the Tradition Minstrelsy in Kayseri
}

OnUr KURALAY*

\section{ÖZET}

Türklerin sahip olduğu kültürel ögelerden biri de âşıklık geleneğidir. Âşıklık geleneği Türk yaşam biçiminde birer hayat okulu işlevini de görmektedir. Gök Tanrı inancından bu tarafa bu gelenek çeşitli değişimlere uğrayarak modern çağda da varlığını sürdürmektedir. Modern çağda bu gelenek, yetkinliğini önceki yıllara göre devam ettiremese de halen önemli kültür unsurları içerisinde yer almaktadır. iç Anadolu Bölgesinde yer alan Kayseri ili, âşıklık geleneğinin önemli merkezlerinden biridir. Birçok âşık bu coğrafyada yetişmiştir. Kayseri'nin Felahiye ilçesine bağlı Acırlı Köyü'nde yaşayan Mazlum Berrakî (Ali Demirpençe), ortaya koyduğu eserler bakımından Kayseri yöresinde âşıklık geleneğinin önemli temsilcilerinden biri olmuştur. Şiirlerinde sosyo-kültürel öğelere çokça yer veren Berrakî, bulunduğu yörenin durumunu adeta şiirleriyle fotoğraflamıştır. Belli bir sistem doğrultusunda şiirlerini muhafaza eden Berrakî, bini aşkın şiirini korumayı başarmıştır. Yüzyıllar öncesinde ve yakın dönemde yaşamış şahıslarla da ilgili önemli şiirleri bulunmaktadır. Bu yüzden Mazlum Berrakî’nin Kayseri âşıklık geleneğinde gün yüzüne çıkartılması hem yöresel kültür bakımından hem de Türk halk kültürü açısından oldukça önemlidir. Bu çalışmada, Âşık Mazlum Berrakînnin tespit edilen şiirleri doğrultusunda Kayseri âşıklık geleneğindeki yeri ve önemi üzerinde durulmuştur.

Anahtar Sözcükler: Kayseri, âşıklık geleneği, âşık, şiir, Mazlum Berrakî

\section{ABSTRACT}

One of the cultural elements that Turks have is the tradition of minstrelsy. Minstrelsy tradition also functions as a life school in the Turkish way of life. From the belief in the Gök Tanrı, this tradition continues its existence in the modern age, undergoing various changes. Although this tradition cannot maintain its competence in the modern age compared to the previous years, it is still among the important cultural elements. Kayseri province, located in the Central Anatolia Re-

\footnotetext{
* Bu çalışma, Nevşehir Hacı Bektaş Veli Üniversitesi Sosyal Bilimler Enstitüsü Türk Halkbilimi Anabilim Dalı'nda 2020 yılında tamamlanan “Mazlum Berrakî’nin Şiir Evreni” adlı yüksek lisans tezinden üretilmiştir.

* Yüksek Lisans Öğrencisi. Nevşehir Hacı Bektaş Veli Üniversitesi, Sosyal Bilimler Enstitüsü, Türk Halk Bilimi Anabilim Dalı, Nevşehir/Türkiye. E-posta: onkuralay@gmail.com. ORCID ID: 0000-0002-1811-2241. 
gion, is one of the important centers of minstrelsy tradition. Many folk poets were brought up in this geography. Mazlum Berrakî (Ali Demirpençe), who lives in Acırlı village of Felahiye district of Kayseri, has become one of the important representatives of the tradition of minstrelsy in Kayseri region in terms of the works he produced. Berrakî, who gives a lot of socio-cultural elements in his poems, photographed the situation of his region with his poems. Berrakî, who preserved his poems in accordance with a certain system, managed to preserve more than a thousand poems. He also has important poems about people who lived centuries ago and recently. Therefore, the unearthing of Mazlum Berrakî in the Kayseri minstrelsy tradition is very important both in terms of local culture and Turkish folk culture. In this study, the place and importance of Mazlum Berrakî in Kayseri minstrelsy tradition has been emphasized.

Key Words: Kayseri, tradition of minstrelsy, minstrels, poetry, Mazlum Berrakî

\section{Giriş}

Mazlum Berrakînin yaşamını sürdürdüğü çevre Kayseri ve yöresidir. Kayserinin jeopolitik konumu da Berrakî'nin bu gelenek içerisinde varlığını sürdürmesinde önemli rol oynamıştır. Kayseri ili konumu gereğiyle İç Anadolu'nun önemli şehirleri arasında yer almaktadır. Kültürel unsurları içerisinde barındırma bakımından da oldukça önemli bir görevi üstlenmektedir. Kayseri ilinin kültürel zenginliği yıllar geçtikçe daha da artmıştır. Çevre illere göre ticari fonksiyonları yüksek bir şehir olmasından dolayı yakın çevredeki birçok ilden göç almıştır. Farklı kültürlerin aynı coğrafyada buluşmasından ötürü ortaya kültürel bir zenginlik çıkmıştır. Makalede ismi geçen Mazlum Berrakî ve ailesi "abdalan” topluluğuyla beraber Malatya'dan Hacı Bektaş Karahöyük'e göç etmiş ve burada ikametgâh sağlamışlardır. Tıpkı Mazlum Berrakî gibi birçok şahıs ve aileleri Kayseri ilinde hâlâ yerleşik olarak hayatlarını devam ettirmektedir.

Kayseri yöresinde sözlü geleneğe dair birçok unsurla karşılaşmak mümkündür. Bu unsurlar arasında "âşıklık geleneği” önemli bir yere sahiptir. Gelenek içerisinde yaratılan âşık şiiri toplumsal bir ayna görevini de üstlenmektedir. Artun'a göre (2003: 34-37), âşık şiiri halk arasında mayalanmış, halkın kültür yapısını, dokusunu şekillendirmekte önemli rol oynamıştır. Toplum bilinciyle âşık şiiri iç içedir. Âşık, toplumun yaşamakta olduğu serüveni sorgulayıp anlamaya çalışarak Türk insanını her boyutuyla kavrayıp aydınlatma çabasıyla Türk kültürünün belirleyici dinamiklerinden birisi olmuştur.

Kayseri'de âşıklık geleneğinin nasıl ortaya çıkıp varlığını sürdürdüğü oldukça önemlidir. Kayseri ilinin yetiştirmiş olduğu âşıkların bir bölümünü 
Fahri Bilge, defterlerinde kayıt etmiştir (Çapraz, 2005). Defterlerde çoğunluğu Afşar aşiretine mensup olan Kayseri ve yöresinde yetişmiş halk şairleri ile gene aynı yöreye dâhil az sayıda divan şairi yer almaktadır. Şairlerin önce biyografileri verilmiş, daha sonra varsa hayatları etrafında teşekkül etmiş anlatılar ve eserlerinden örnekler kaydedilmiştir. Özellikle şiirlere bağlı olarak aktarılan anlatılar Afşarların sözlü tarihini yansıtmaktadır (Çapraz, 2005: II). Sözlü tarihin aktarımı sözel bellek dinamiklerini (Ekmekçi, 1991) korumuş ve kültürel unsurların günümüze kadar gelmesine katkıda bulunmuştur.

Âşıkların kültürel unsurları taşıyıcılık yönü de oldukça önemlidir. Bu bakımdan Berrakî kendi yöresine ait birçok unsuru eserlerinde zikretmiştir. Arslan'a göre (2015: 3), kültürel bellek taşıyıcılığı açısından âşık, gelenek içinde ustalardan edindiği geçmişi hatırlamanın temel figürlerini, içine doğduğu toplumun bizatihi kökenine ve varlığına ilişkin dini, milli, sosyal ve kültürel kodlamalarını, ritüel sunu özelliğine sahip icralar sırasında ve özellikle katılımcı grupla yüz yüze kurulan iletişim yoluyla aktarmaktadır.

Âşıkların genelde etkin olduğu alanlar toplumsal bütünleşmenin gerçekleştiği alanlarda olmuştur. Bu alanlar arasında kahvehaneler, köy meydanları, köy odaları, panayırlar, bozahaneler, okullar, meyhaneler (Çobanoğlu, 2000: 134; Tek, 2004: 4; Çapraz, 2018: 236-237) gibi alanlar bulunmaktadır. Bunun yanı sıra âşıklar, toplumu yakından ilgilendiren çeşitli özel günlerde de boy göstermişlerdir.

Kayseri ve yöresinde Alevi-Bektaşi kültürünün izlerini çok yakından görmek mümkündür. Bu kültür oluşumu çevresinde Türk halk kültürüne önemli eserler kazandırılmıştır. Doğan'ın ifadesiyle "Alevi-Bektaşi edebiyatı kendi anlayışını en iyi şiirle ifade etmiştir.” (2012: 34). Âşık Berrakî’nin şiirlerine bakılırsa bu şuur yerinde mefhumlarla işlenmiştir. Kayseri'de bu kültür katmanının mevcudiyeti âşıklık geleneğinin zenginleşmesindeki en önemli faktörlerden biridir. Âşıkların şiirlerinde ele aldığı bireysel ve toplumsal faktörler onların bu sahadaki varlığını daha anlamlı kılmıştır:

“Âşıkların özellikle cumhuriyet, ordu, askerlik, ülke bütünlüğü, Kıbrıs meselesi, ortak pazar, Avrupa, Almanya, gençlik, pop müzik, din ve ahlak kaygısı, örf adet endişesi, değerlere bağlıık, geçim darlığı, hayat pahalılığı, toplumsal eleştiri, halkın protesto ihtiyacı, mahalli problemler gibi toplumsal; göç, gurbet duygusu, sıla hasreti, zaman değişmesi gibi ferdi konulan dile getirmeleri ve bu konularda söylediklerini geniş kitlelere duyurmaları onları ayakta tutan hususlardır." (Özarslan, 2001: 171-172). 
"Köylerde yetişen âşıklar, geçmişte klâsik edebiyat ve aruz ölçüsünün, günümüzde ise modern edebiyatın ve buna bağlı nazım şekillerinin etkisinden oldukça uzaktırlar. Şehir âşıklarının farklı etkiler altında gelişen dil ve üslûplarına karşılık, onlar tümüyle içinde yasadıkları halkın dilini kullanırlar, halkın konularını terennüm ederler. Köylere kadar uzanan tekke kültürüne ait unsurların etkisiyle çok yüzeysel de olsa- bazen dinî-tasavvufî konularda ürün verirler. Bununla birlikte köyde yetişen âşıklar da bağlı bulundukları şehrin olanaklarını belli ölçülerde kullanırlar, il ve ilçelerdeki meslektaşları ile zaman zaman bir araya gelerek karşılıklı etkileşim içine girerler." (Düzgün, 2004: 191).

Mazlum Berrakî’nin şiir üslubuna bakıldığında bazı farklılıkları görmek mümkündür. Aruz ölçüsüne çoğu şiirlerinde yer vermese de klâsik edebiyata ait birçok unsura şiirlerinde yer vermiştir. Bu şiirlerinde yer alan çoğu kelimeler bulunduğu yörenin günlük konuşmalarında kullanılan kelimelere oldukça uzaktır. Bu şiirlerdeki arka planı anlamak için edebi bilgiye sahip olmak gerekmektedir.

Âşıklık geleneğinin icra töresi kahvehanelerde şekillenmiştir (Çobanoğlu, 2006: 28). Kayseri âşıklık geleneğine bakıldığında, Kayseri Âşıklar Kahvesi'nin oldukça önemli işlevleri bulunmaktadır:

“Kayseri Âşıklar Kahvesi, açıldığı günlerden itibaren âşıklık kültürünün her türünün icra edildiği, yörenin ve civar yörelerin çok önemli âşıklarının sahne aldığı, doğu ve batı arasında seyahat eden âşıkların konakladığı, ramazanlarda, önemli gün ve gecelerde Kayseri halk kültürünün nabzını tutmuş bir mekândır. Kahve aynı zamanda genç nesiller için âşıklık kültürünü tanımanın yanında bağlama çalmayı öğrendikleri, icralarını geliştirdikleri, halk kültürü ile ilgili her tür bilgiye sahip kişilerin kaynak olduğu bir yer olma özelliği ile bir tür okul olmuştur." (Istanbullu, 2018: 23).

\section{Mazlum Berrakî’nin Hayatı ve Gelenekteki Yeri}

Asıl adı Ali Demirpençe'dir. 1947 yılında Kayseri'nin Felahiye ilçesinin Acırlı köyünde yoksul bir ailenin evladı olarak dünyaya gelmiştir. Babası Mazlum Abdal evlatlarından Mustafa (Dede), annesi ise Leyla Ana'dır. Ortaokul mezunudur. Yoksul ve kalabalık bir ailenin çocuğu olduğu için daha küçük yaşlardan itibaren çalışmaya başlamıştır. Kayseri Büyükşehir Belediyesi'nde şoför olarak çalıştıktan sonra emekli olmuştur. Hâlen Kayseri'de ikamet etmektedir. Mazlum Berrakî'nin ailesi Kayseri iline sonradan göç etmiş bir ailedir. Bu ailenin asıl lakaplarına "pir delisi" denmektedir. 
Mazlum Berrakî'nin ailesiyle beraber birçok aile de Malatya'dan Kayseri'ye ve Sivas'ın bazı bölgelerine göç etmişlerdir ${ }^{3}$.

Âşık Mazlum Berrakî, şiire küçük yaşta merak salmıştır. Berrakî’yi şiirle tanıştıran kişi babasıdır. Berrakî’nin babası da kendi usulünce şiirler yazmıştır ve bazı âşık arkadaşları bulunmaktadır. Berrakî de bu bağlam içerisinden etkilenip kendisini bu yöne doğru yönlendirmiştir. Babasının deyişlere, duvazı imama, Nesimî’ye ve Şah Atayi'ye yoğun bir ilgisi vardır. Bu yüzden Berrakî, ilk ustasının babası olduğunu ifade eder. Mazlum Berrakî asıl şiirlerini yazmaya 17 yaşında başlamıştır. Bâdeli bir âşık değildir. Âşıklık geleneğinde önemli bir yere sahip olan "rüyada âşık olma" Berrakî'nin farklı bir yorumu vardır. Bu yorum şu şekildedir: "Eğer pak bir insansan badeyi Cenab-ı Allah ruhlar âleminde içirip gönderir. Bir insan o saflığı o temizliği koruyabiliyorsa ikinciye ne gerek var. O zaman ikrardan dönmüş olursun. Hamdolsun biz 'elestte' içiysek o bize yeter. Yani ben o rüya işine inanmıyorum.” (KK-1).

Mazlum Berrakî, babasının arkadaşı olan ve "Çileli Âşık" da denilen Tomarzalı Muhsin'in yanında uzun bir çıraklık dönemi geçirmiştir. Tomarzalı Muhsin, Berrakî̀yi sık sık tenkit etmiştir. Berrakî bu tenkitler sayesinde pek çok şeyin farkına vardığını ifade eder. Bunun yanı sıra Berrakî, Tomarzalı Muhsin'in arkadaşı olan Kadimî'den de etkilenmiştir. Berrakî'ye Mazlum diye hitap eden ilk kişi Tomarzalı Muhsin'dir. Berrakî mahlasını ise Mehmet Çoban vermiştir. Mehmet Çoban, Berrakîyye bu mahlası gönlünün saflığından ve berraklığından dolayı verdiğini ifade etmiştir. Daha sonraları Çileli Âşık, Mehmet Çoban ve Mazlum Berrakî arasında çok iyi bir uyum sağlanmış ve gelenek üzerine pek çok sohbetler etmişlerdir. Çeşitli âşıklarla edilen bu sohbetler Berrakî̀yi pişirmiş ve alanında yetkin şiirler vermesine vesile olmuştur. Mazlum Berrakî, kimi zaman Hunak Cami'si yanındaki yerlerde Âşık Baba ve bazı dostlarıyla da irticalen atışmalar yapmıştır. Yazmış olduğu çoğu şiirinin hikâyesi bulunmaktadır.

Berrakî, âşık tarzı şiir geleneğine bağlı olup daha ziyade dinî ve tasavvufî çizgide eserler vermiştir. Berrakînnin sayısı bini aşkın şiiri bulunmaktadır ve bu şiirlerini beş adet defterde toplamıştır. Bu şiirler belirli bir düzen içerisinde muhafaza edilmiştir. Her şiirine birer numara verilmiş ve yazıldığı tarih şiirlerin üst kısımlarında belirtilmiştir. Bazı şiirlerin yer ve mekânlarına hatta küçük hikâyelerine şiir defterlerinde yer verilmiştir. Ayrıca gerek eserlerinden gerekse tabi olduğu Alevi-Bektaşi aileye bağlı olması dolayı-

\footnotetext{
${ }^{3}$ Hayatı ile ilgili ayrıca bk. (Kalkan, 1988: 246; Acı, 2015: 86).

${ }^{4}$ Ayrıntılı bilgi için bk. (Günay Türkeş, 2008).
} 
sıyla Berrakî’nin Alevi-Bektaşi geleneği içerisinde yer aldığını ifade edebiliriz. Şiirlerinde Yunusvari bir söyleyiş vardır. Yöre ağzı deyişleri de içeren anlatımı yalın ve içtendir. Şiirlerinde ölçü olarak hece ölçüsünü; şiir tarzı olarak da koşma, semai ve destanlara yer vermiştir. Şiirlerinde genel olarak Hacı Bektaş Veli, Hz. Ali, On İki İmam, Atatürk ve Kayseri temaları yoğunluklu olarak görülmektedir. Alevî-Bektaşî şiir kültürünün arka planındaki edep ve erkânın en güzel betimlemelerini Mazlum Berrakî'nin şiirlerinde görmek mümkündür. Berrakî, Alevî-Bektaşî geleneğinde icazetli bir âşık olması bakımından da oldukça önemlidir. Aşığın kendisini takdim ettiği bir şiiri şöyledir:

Yeşil olur şu Acır'ın bağları

Ekşi tatlı biter bizim meyveler

Lale, nergis kokar bütün dağları

Burcu burcu kokar açan o güller

Kızılırmak taşkın akar baharda

Kumruları coşkun öter seherde

Kekikleri aşkın biter ceherde

Bahar ayı coşar akar o seller

Yoncalık'ta öter keklik sürüsü

Meşelik'te dünek tutar yarısı

Karaoyun'da açar nergis sarısı

Türlü türlü nâme yapar bu diller

Beş kız yüksek uçan kuşu getirir

Evliyada türlü sırlar bitirir

Killi Baba makamında oturur

Dört taraftan eser gider o yeller

Tuz Taşı da Kurşunlu'ya bakıyor

Tapanlı da kumru bülbül şakıyor

Pınarından soğuk sular akıyor

Kervan konmaz yol geçirmez o beller

Çevre köyü birer birer söyleyim

Şu Gürden'i yıkıp hasar eyleyin

Bölveren'i sevin hisar eyleyin

Çevremizde komşu olur bu eller 
Hırka Köyü karman çorman görünür

Menteşe de külli kire bürünür

Alabaş da deli kisve sarınır

Ayna gibi ayan durur bu haller

Mazlum Abdal evliyaya sır katar

Kalp evinden gönüllere nur akar

Arıları zemheride bal yapar

Sır ehlinden sır söylüyor bu diller

Bu halkımız birbiriyle sevişir

ilim teknik aydın insan yetişir

Çocuk okur âlim olur erişir

Candan cana kaynar gider gönüller

Erciyes dağımdır, Kayseri ilim

Felahiye kazam, Acırlı köyüm

Mazlum Berrakî̀yim daha ne deyim

Halimizden bilmez bizim yâd eller (KK-1).

Âşığın şiirleri genel olarak beş kıtanın üzerindedir. Bu şiirlerin bazılarını da cezaevinde kaldığı sıralarda yazmıştır. Âşığın bazı şiirleri de oldukça dikkat çekicidir. Görmüş olduğu veya hatırası olan bir nesneye dahi şiir yazmıştır. Ancak Mazlum Berrakî, en yetkin şiirleri arasında şahıslara yazmış olduğu şiirlerine ayrı bir önem vermiştir. Dini tasavvufi çizgide birçok şiiri bulunan âşığın, bu şahıslar nezdinde önemli şiirleri bulunmaktadır.

Gönül arzuladı Hacı Bektaş'।

Varıp dergâhına sürsem yüzümü

Nasip olsa görsem güzel Bektaş’।

Alıç ağacında yesem üzümü

Delik taşa varıp geçsem oradan

Yürütse gemisin pirim karadan

Çilehanede zemzem suyu yaradan

Arıtıp paklasam kendi özümü

Deliktaş'tan sığırtmaca erişsem

Cemâl görüp erenlere karışsam

Deyiş duaz töreninde yarışsam 
Muhabbet şekeri etsem sözümü

Erişsem tekkeye girsem içeri

Yoldaş olsa bana Hızır Nebi

Kandilde erisem fitil yağ gibi

Coşa gelip orda deşsem közümü

Şah Balım Sultan'ın cemâlin görsem

Eğilip postuna yüzlerim sürsem

Cevahir verilen dükkâna girsem

Hâk erenler açsın gönül gözümü

Mazlum Berrakî der dergâha girsem

Musahip kavlinde ikrarım versem

Tazece açılmış güllerin dersem

Can gözüyle görsem pirim yüzünü (KK-1).

Berrakînnin Âşık Seyrani şenliklerinde okumuş olduğu şiirleri de bulunmaktadır. Ayrıca Kayseri'de bulunan Âşıklar Kahvesi'nde de irticalen çeşitli atışmalara katılmıştır. Ancak Berrakî, bir müddet sonra saz çalmayı kardeşinin ölümünden duyduğu üzüntü üzerine bırakmış ve bir daha çalmamak üzere yemin etmiştir. Berrakî, günümüzde de halen şiir yazmaya devam etmektedir. Etrafındaki birçok kişiye ara ara şiirlerini paylaşmaktadır. Bu şiirlerin bazıları Kayseri'nin çeşitli dergilerinde yayınlanmıştır. Yetiştiği gelenek içerisinde belli bir ustaya tabi olmadan şiirlerini yazıya döken Berrakî, her çiçekten bal almasını bilen bir âşık olmuştur. Kayseri'nin önde gelen üç-dört âşığından sağlam bir şekilde beslenmiştir. Çoğu âşık gibi yoksulluk ve gurbetlik gibi hayat şartlarında yoğrulan Âşık Berrakî, şiirlerine bu duyguyu başaralı bir şekilde katmıştır.

\section{Mazlum Berrakînnin Şiir Defterleri}

Âşık Mazlum Berrakî, 1985'ten itibaren şiirlerini defterlere kayıt etmeye başlamıştır. Her şiirin yazılış tarihi gün, ay ve yıl olarak belirtilmiştir. Ayrıca şiirler numaralandırma yöntemiyle daha tertipli bir hale getirilmiştir. Berrakî, kimi şiirlerinin yanına duymuş olduğu veya kendi tecrübelerine bağlı olarak ifade ettiği özlü sözleri de kayıt altına almıştır. Bazı şiirlerinin küçük bir hikâyesini ve yazııı̧ yerlerini de şiir defterinde ayrıca belirtmiştir. Kayseri ve yöresinde çeşitli dergilerde yayınlanan şiirlerinin altına yayınlandığı dergiler hakkında da bilgi vermiştir. Daha önce belirttiğimiz gibi âşığın beş adet şiir defteri bulunmaktadır. Şiirlerini günümüzde beşinci deftere kayit etmeye devam etmektedir. 


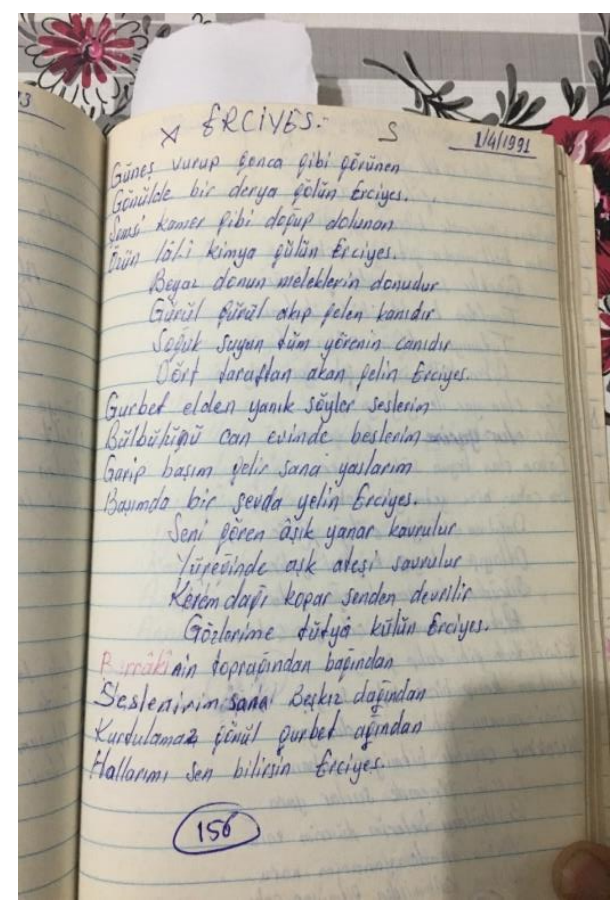

Görsel 1: Berrakî'nin şiir defterlerinden bir sayfa (Berrakî Arşivi)

\section{Mazlum Berrakî'nin Şiirlerinde Tür ve Şekil}

Âşık Berrakî, bini aşkın şiirinde halk şiirinin ve klâsik şiirin birçok türü ile ilgili eserler kaleme almış ve çeşitli şekiller kullanmıştır. Berrakînnin şiirlerinde kullandığı âşık edebiyatı nazım şekilleri, koşma destan ve semaidir. Berrakî'nin şiirlerinde kullandığı âşık edebiyatı nazım türleri ise, güzelleme, ağıt ve destandır. Berrakî’nin şiirlerinde kullandığı aruz şekli divandır. Ayrıca Berrakî'nin şiirlerinde kullandığı tekke edebiyatı nazım türleri, nefes, devriye, düvaz/düvazıimam, hikmet, na't, medetname, ayetlemedir. Âşık, hece ölçüsü olarak genellikle 8'li ve 11'li hece ölçüsüyle şiirler kaleme almıştır. Bunun yanı sıra aruzun "fâilatün/ fâilatün/ fâilatün/ fâilün" kalıbıyla da şiirler kaleme almıştır.

\section{Sonuç}

Kayseri âşıklık geleneği, uzun bir geçmişe ve Türk kültüründe önemli bir işleve sahiptir. Kayseri'de varlığını çeşitli yollar vasıtasıyla devam ettiren bu gelenek, iç Anadolu'daki âşıklık geleneğinin ana damarlarından biri haline gelmiştir. Yetiştirmiş olduğu önemli âşıklarla birlikte sözel kültürün kuşaktan kuşağa yayılmasında öncü yöreler arasında bulunmaktadır. Yakın yıllarda Kayseri Halk Ozanları Derneği üyelerine bakıldığında başka illerden gelip âşıklık vazifesini burada devam ettiren kişilerin bulunduğu anlaşılmaktadır. Âşıklık geleneğine olan ilgi yıllar geçtikçe azalmaya baş- 
lamıştır. Bu çerçevede günümüzde pek çok âşık keşfedilmeyi beklemektedir. Keşfedilmeyen âşıklar ise şiirleriyle beraber tarih olmaktadır. Çoğu kültür unsurunun unutulduğu bu dönemde özellikle âşıklık geleneğiyle ilgili bir farkındalık yaratmak oldukça önemli olacaktır. Çünkü incelenen bazı şiirler gerçekten ait olduğu yörenin sosyokültürel faktörlerine ışık tutmaktadır. Araştırmamızda ismi geçen Mazlum Berrakî de bu hususta Kayseri âşıklık geleneği için öneme sahip bir âşıktır. Beş adet defterde bulunan şiirlerin çoğu incelendiğinde önemli kültürel portrelerle karşılaşmak mümkündür. İyi bir eğitim almamasına rağmen dini-tasavvufi çizgide önemli bir kelime haznesine sahip olan Âşık Berrakî'nin klâsik edebiyat çizgisi de araştırılmaya değerdir. Berrakî, Bektaşi şiir geleneğinin çizgisinde eserler vererek geleneğin taşıyıcı kollarından birisi olmuştur. Şiirlerinde aşk, insan sevgisi ve dini çerçeve gibi temaları temel alarak Türk halk kültürüne önemli katkılar sağlayacağı aşikârdır.

\section{Kaynakça}

Acl, Kadir (2015). Başlangıçtan Günümüze Felahiyeli Şair ve Yazarlar Güldestesi. Kayseri: Şiirvakti Yayınları.

Arslan, Mustafa (2015), "Kültürel Belleğin Uzman Taşıyıcıları Olarak Âşıklar”. Türk Dünyası incelemeleri Dergisi, 15(1): 1-6.

Artun, Erman (2003). "Osmanlı-Türk Kültüründe Âşık Şiirinin Belirleyici Rolü”. Folklor Halkbilim Dergisi, 6/51: 34-37.

Çapraz, Erhan (2005). Fahri Bilge Defterlerindeki Kayseri ve Yöresi Halk Şairleri. Yüksek Lisans Tezi. Kayseri: Erciyes Üniversitesi Sosyal Bilimler Enstitüsü.

Çapraz, Erhan (2018). "Âşık Tarzı Şiir Geleneğinin Teşekkülüne Dair Değerlendirmelere Bir Ek: Meyhaneler”. Türkbilig, 35: 233-244.

Çobanoğlu, Özkul (2000). Âşık Tarzı Kültür Geleneği ve Destan Türü. Ankara: Akçağ Yayınları.

Çobanoğlu, Özkul (2006). Eminönü Merkezli Âşık Edebiyatı. İstanbul: Eminönü Belediyesi Yayınları.

Doğan, Metin (2012). Derviş Muhammed Kolunda Gelenek, Etkileşim, Eğitim ve Âşıkînin Şiir Anlayışı. Yüksek Lisans Tezi. İzmir: Dokuz Eylül Üniversitesi Eğitim Bilimleri Enstitüsü.

Düzgün, Dilaver (2004). "Âşık Edebiyatı”. Türk Halk Edebiyatı El Kitabı. (Editör: M. Öcal Oğuz). Ankara: Grafiker Yayıncılık. 
Ekmekçi, F. Özden (1991). "Sözel Bellek ve Hatırlama". Dilbilim Araştırmaları Dergisi, 2: 50-58.

Günay Türkeş, Umay (2008). Türkiye'de Âşık Tarzı Şiir Geleneği ve Rüya Motifi. Ankara: Akçağ Yayınları.

istanbullu, Seranat (2018). "Kayseri'de Bir Âşık Okulu: Âşıklar Kahvesi”. Social Sciences Research Journal, 7(1): 22-30.

Kalkan, Emir (1988). Çağlar Boyunca Kayseri Şairleri. Kayseri: Kayseri ili Özel İdare Müdürlüğü ve Kayseri Belediyesi Birliği Yayınları.

Özarslan, Metin (2001). Erzurum Âşıklık Geleneği. Ankara: Akçağ Yayınları. Tek, Recep (2004). Türk Halk Şâirleri: Azmi, Şâzi, Pervâne. Yüksek Lisans Tezi. Kayseri: Erciyes Üniversitesi Sosyal Bilimler Enstitüsü.

URL-1: “Kayseri'ye Değer Katan i̇simler”. https://kayseri.ktb.gov.tr/TR55149/kayseri39ye-deger-katan-isimler.html. (Erişim:06.09.2020).

\section{Sözlü Kaynaklar}

KK-1: Ali Demirpençe, 1947 doğumlu, ilkokul mezunu, emekli, Kayseri. (Görüşme: 26.12.2019). 